\title{
1999'dan 2002 Genel Seçimlerine Giden Süreçte Türkiye'de Kritik Yeniden Saflaşma ve Kritik Seçim Teorisi Üzerine Bir Değerlendirme
}

\author{
Arş. Gör. Kinem Tokdemir ${ }^{1}$ \\ Arş. Gör. Aykut Karakuş ${ }^{2}$
}

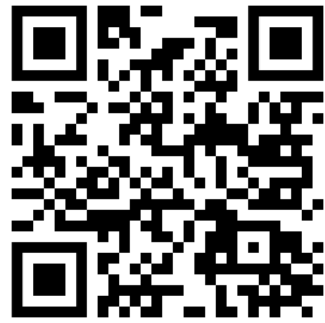

Geliş tarihi: 28.09.2020

Kabul tarihi: 25.12 .2020

Atıf bilgisi:

IBAD Sosyal Bilimler Dergisi

Sayı: Özel Sayı Sayfa: $730-748$

Yil: 2020

This article was checked by Turnitin. Similartiy Index 13\%

Bu makalede araştırma ve yayın etiğine uyulmuştur. ${ }^{1}$ Beykent Üniversitesi, Türkiye,
kinemtokdemir@ beykent.edu.tr , ORCID ID 0000-0003-4149-1726

${ }^{2}$ Beykent Üniversitesi, Türkiye, aykutkarakus@beykent.edu.tr , ORCID ID 0000-0002-4053-2074

\section{* Sorumlu yazar}

$\ddot{O Z Z}$

Seçimler, demokratik toplumlarda vatandaşların yönetime katılımının sağlanması ve hükümetin kurulması için önemli ve vazgeçilmez bir araçtır. Seçimler sonunda seçmenlerin oylarıyla bürokratik ya da siyasi görevleri üstlenecek ve iş başına gelecek kişiler belirlenir. Ancak seçimler, yalnızca bir seçme eylemi değildir zira bir sürecin parçasını da oluşturmaktadır. Dolayısıyla seçmenin oy verme davranışları çeşitli faktörlere göre değişirken; bu faktörlerin hangi çerçevede değiştiğinin anlaşılması seçmenlerin kritik yeniden saflaşmaları ve kritik seçimlerin ortaya çıkmasının anlaşılması için önemlidir. Kritik seçim teorisi, seçim dönemlerinde seçmenlerin süregiden bir durumu ani ve radikal bir biçimde değiştirecek yeniden saflaşmasını ifade eder. Kritik yeniden saflaşmalar ve kritik seçimler sonucunda seçime giren partilerin önceki seçimlere göre oyları artar veya oylarda radikal bir azalma yaşanır. Bu teoriye göre seçmenlerin oy verme davranışı oy verilen partiye duyulan memnuniyetsizlik, sosyo-ekonomik durum, dış politika, seçmen psikolojisi, lider etkisi veya seçim zamanlarında partilerin kullandıkları söylemler gibi birçok etmene göre değişebilmektedir. Türkiye'de 1999'dan 2002'ye giden süreçte ekonomik, siyasi ve toplumsal alanlarda gerçekleșen iç ve dış dinamikler, seçmenlerin oy kullanma tercihi üzerinde etkili olmuştur. Bu bağlamda bu makalede kritik yeniden saflaşma ve kritik seçim teorisi ışığında Türkiye'de 18 Nisan 1999 genel seçimlerinden 3 Kasım 2002 genel seçimlerine giden süreç, iç ve dış dinamikler çerçevesinde incelenmiştir. Çalışmada öncelikle kritik yeniden saflaşma ve kritik seçim teorisi üzerinde durulmuştur. Ardından Türkiye'de belirtilen süreçte iç ve dış dinamikler ayrıntılı olarak incelenmiştir. Bu çalışmada, seçimlerden başarılı bir sonuç alan Genç Parti ve Adalet ve Kalkınma Partisi üzerinden bir değerlendirme sunulmuştur. Genç Parti'nin yükselişi ve Adalet ve Kalkınma Partisi'nin koalisyon hükümetlerinin ardından tek parti hükümeti kurması konu bağlamında analiz edilmiştir. Çalışmada Türkiye'de 1999 ve 2002 genel seçimlerinin siyasi, ekonomik, sosyal yapısını iç ve dış dinamikler bağlamında çözümlemek, "kritik yeniden saflaşma" ve "kritik seçim" ile ilgili kavramsal ve metodolojik tartışmanın ana hatlarını oluşturmaktadır.

Anahtar Kelimeler: Kritik Yeniden Saflaşma, Kritik Seçim, İç ve Dış Dinamikler, Seçmen Davranışı, Genç Parti, Adalet ve Kalkınma Partisi. 


\title{
An Assesment on Realignment and Critical Election Theory in Turkey in the Process From 1999 to the 2002 General Elections
}

\author{
Res. Assist. Kinem Tokdemir ${ }^{1}$ \\ Res. Assist. Aykut Karakuş ${ }^{2 *}$
}

First received: 28.09 .2020

Accepted: 25.12 .2020

\section{Citation:}

IBAD Journal of Social Sciences

Issue: Special Issue Pages: 730-748

Year: 2020

This article was checked by Turnitin. Similartiy Index 13\%

${ }^{1}$ Beykent University, Turkey, kinemtokdemir@beykent.edu.tr, ORCID ID 0000-0003-4149-1726

${ }^{2}$ Beykent University, Turkey, aykutkarakus@beykent.edu.tr, ORCID ID 0000-0002-4053-2074

\section{* Corresponding Author}

\begin{abstract}
Elections are an important and indispensable tool for ensuring the participation of citizens in government and the formation of a government in democratic societies. At the end of the elections, voters' votes determine who will take on bureaucratic or political duties and undertake the job. But elections are not just an act of choice, because they also form a part of a process. Thus, while voting behaviors of the voters vary according to various factors, understanding the context in which these factors change is important for understanding the critical re of the voters and the emergence of critical elections. Critical election theory refers to the realignment of voters during election periods that will suddenly and radically change an ongoing situation. As a result of critical realignment and critical elections, the votes of the parties entering the election increase or decrease radically compared to the previous elections. According to this theory, the voting behavior of voters can vary according to many factors, such as dissatisfaction with the party, socio-economic situation, foreign policy, voter psychology, leader influence, or the rhetoric used by parties at election times. Internal and external dynamics in Turkey in the economic, political and social areas during the period from 1999 to 2002 have had an impact on voters' choice to vote. In this context, this article reviews the process in Turkey from the general elections of 18 April 1999 to the general elections of 3 November 2002 in light of re-division and critical election theory within the framework of internal and external dynamics. First, the study focused on critical realignment and critical election theory. Then, internal and external dynamics were examined in detail in the relevant process of Turkey. In this study, an assessment presented on Young Party and Justice and Development Party, which achieved successful results in the elections. The rise of the Young Party and the establishment of a single-party government by the Justice and Development after the coalition governments have been analyzed within the scope of the subject. The aim of the study is to analyze the political, economic and social structure of 1999 and 2000 General Elections in Turkey within the context of the internal and external dynamics and form an outline of the contextual and methodological discussion regarding the "critical realignment" and "critical election".
\end{abstract}

Anahtar Kelimeler: Critical Realignment, Critical Election, Internal and External Dynamics, Voter Behavior, Young Party, Justice and Development Party. 


\section{GíRIŞ}

Günümüzde bireylerin, ülkenin nasıl yönetileceği ile ilgili görüşlerini sunmasının başlıca yolu seçimlerdir. Seçimler yoluyla farklı bürokratik ve siyasi görevlere gelecek kişiler belirlenebilir (Dikici Bilgin, 2016, s. 147). Demokratik toplumlarda siyasi katılımın önemli araçlarından biri olan seçimler, seçmenlerin oylarıyla iş başına gelecek kişilerin belirlendiği iletişim mekanizmalarıdır. Dünyadaki birçok ülke, düzenli ve periyodik seçimleri, demokrasinin temel bir özelliği olarak görmektedir. Seçim sistemleri, kimin kazandığını ve kaybettiğini belirlerken, seçim sonucunda hükümetin oluşturulmasını güçlü bir şekilde etkilemektedir. Öte yandan seçimler, yalnızca seçme eylemi değildir. Seçimler, bir sürecin parçasını da oluşturmakta ve böylece iktidardaki liderin sürekliliğini ya da değişimini belirlemektedir (Sisk, 2017, s. 2-3). Seçim yoluyla siyasi sisteme katılımın sağlanması, bu anlamda oy kullanmanın ötesinde bir süreci ifade etmektedir. Nitekim 1999 genel seçimlerinden 2002 genel seçimlerine giden süreçte Türkiye'de ve dünyada gelişen dinamikler, seçmenin oy verme davranışını etkilemiştir. Dolayısıyla siyasal katılmada farklı davranışlar olabileceği gibi kişilerin siyasal sistem karşısında davranışlarını etkileyen dinamikler de önemlidir. Bu faktörler siyasi ve sosyo-ekonomik faktörler olabileceği gibi psikolojik, kültürel veya çevresel de olabilmektedir (Kapani, 2012, s. 146). Sosyo-ekonomik ve politik yapıda meydana gelen köklü ve ani olaylar karşısında seçmenlerin farklı partilere yönelmeleri, oy verme davranışının ve parti desteğindeki değişimlerin bir ifadesidir.

$\mathrm{Bu}$ bağlamda oy verme davranışıyla ilişkili yapılan yaklaşımlara değinmek gerekir. Bu yaklaşımlardan biri olan sosyolojik yaklaşımlar, insanların çıkarlarına en uygun olan partiye oy verdiklerini ifade eder. Sosyolojik yaklaşımlara göre, oy kullanma davranışını etkileyen faktörler ise dil, din, kimlik, ırk, kentkır farklılıkları ve kimi zaman da toplumsal cinsiyet ve iş farklılıklarıdır. Diğer bir yaklaşım ise psikolojik yaklaşımlardır. Sosyolojik yaklaşımlar toplumu baz alırken, psikolojik yaklaşımlar bireysel özelliklere vurgu yapar. Bu yaklaşıma göre parti ile özdeşleşme, işsizlik, ekonomik gelişme, parti programlarındaki farklılıklar ve lider imajları oy verme davranışını etkilemektedir. Diğer bir yaklaşım ise, rasyonel seçim teorisidir. Bu yaklaşıma göre ise vatandaşlar rasyonel oldukları için hangi parti onların öz çıkarlarını karşılıyorsa o partiye oy verir (Newton ve van Deth, 2014, s. 261-263). Bir başka yaklaşım ise, stratejik oy verme modelidir. Bu yaklaşıma göre, seçmenler, yapılan seçimler sonucunda hangi senaryoya ulaşmak istiyorsa ona göre hareket ederek kurduğu stratejiyi uygular. Örneğin, oy verilen parti tek başına hükümet kuramıyorsa, seçmen bu parti ile koalisyon hükümeti kurulması istenen partiye oy verebilir (Aydoğan Ünal, 2016, s. 111).

Böylelikle seçmen davranışının çok boyutlu olduğu ve birçok faktörü içerdiği söylenebilir. Örneğin, Abadan'a göre sosyo-ekonomik açıdan kötü yaşam koşullarına sahip olan seçmenler, seçimleri bir firsat olarak görüp seçimlere katılım gösterirken; özellikle taşrada yaşayan muhafazakâr yapıya sahip seçmenler, statükonun korunması amacıyla seçimlere tedirgin yaklaşmaktadırlar (Abadan ve Yücekök, 1966, s. 102-118 ). Ancak bir çalışmasında Abadan, bu davranış biçimini seçmenlerin mevcut sosyoekonomik durumlarıyla ilintili olarak ilgi duydukları alanlara göre değişmesi olarak yorumlamıştır. Diğer bir deyişle Abadan, seçmenlerin mevcut gelirlerinin oy verme davranışları üzerinde etkili olduğunu ifade etmiştir (Abadan, 1965, s. 496-517). O halde, seçimlerde seçmenlerin sandığa gitmeleri ve oy verme davranışlarının hangi çerçevede şekillendiği, seçim sonuçları açısından oldukça önemlidir. Dolayısıyla seçmen tercihlerinin şekillenmesinde çeşitli dinamiklerin etkileri göz önünde bulundurulmalıdır.

Türkiye'de 1999-2002 genel seçimleri arasındaki süreçte gelişen iç ve dış dinamikler, kritik yeniden saflaşma ve kritik seçim olgularını çözümlemek adına oldukça önemlidir. 1999-2002 yılları arasında Türkiye'de seçmenin oy verme davranışlarını etkileyen unsurlar, koalisyon hükümetlerinden sonra ilk defa bir partinin hükümeti kurmasıyla sonuçlanmıştır. Söz konusu tarihlerde geçen süreçte Türkiye'de iç ve dış dinamikler analiz edilerek kritik yeniden saflaşmalara ve bunun neticesinde kritik seçimlere yol açan faktörler anlaşılabilir. Dönemin Cumhurbaşkanı Süleyman Demirel'in DSP'den (Demokratik Sol Parti) Bülent Ecevit'i görevlendirmesi ve ANAP'in (Anavatan Partisi) da dâhil olmasiyla birlikte, 28 Mayıs 1999'da DSP-MHP (Milliyetçi Hareket Partisi)-ANAP hükümeti kurulmuştur. 3 Kasım 2002 seçimlerinde ise siyasi iklimde farklı bir durum ortaya çıkmış ve Adalet ve Kalkınma Partisi (Ak Parti) tek başına hükümeti kurmasını sağlayacak oyların çoğunluğunu almıştır. 2002 erken seçimlerinden 
henüz bir yıl önce kurulmuş Ak Parti’nin \%34.3 oy ile tek başına iktidara gelmesi bir sürpriz olarak karşılanmıştır. Ak Parti'nin seçimlerin galibi olmasının yanında, bir önceki seçimlerde barajı geçemeyen CHP'nin (Cumhuriyet Halk Partisi) Deniz Baykal önderliğinde \%19 oy ile ikinci parti olarak yükselmesi de önemlidir. Çünkü bir önceki seçimlerde iktidarda ve mecliste çoğunluğu sağlayan DSP, MHP, ANAP, DYP (Doğru Yol Partisi), SHP (Sosyal Demokrat Halkçı Parti) barajın altında kalmış ve şaşırtıcı bir sonuç ortaya çıkmıştır. Öte yandan kısa bir sürede örgütlenen Genç Parti’nin (GP) de \%7.2 oy alarak bu seçimlerden başarı ile çıkması da beklenmedik bir sonuç olmuştur.

Bu minvalde çalışmanın yöntemi, araştırma nesnelerini oluşturan yazılı kaynak ve metinlerin okunması ve analiziyle ortaya atılan problemin çözümlenmesine dayalıdır. Makalede Türkiye'de 1999 ve 2002 genel seçimlerinin siyasi, ekonomik, sosyal yapısını iç ve dış dinamikler bağlamında çözümlemek, "kritik yeniden saflaşma" ve "kritik seçim" ile ilgili kavramsal ve metodolojik tartışmanın ana hatlarını oluşturmaktadır. 3 Kasım 2002 genel seçimlerinin sonuçlarını geriye dönük incelediğimizde çeşitli dönemlerde kritik yeniden saflaşmanın meydana geldiği ve beklenmedik sonuçlara yol açan kritik seçim teorisi anlaşılabilir. O halde şu sorular sorulabilir: 1999 genel seçimlerinde iktidardaki koalisyon partisini, 2002 genel seçimlerinde yenilgiye uğratan sebepler nelerdi ve 2002 genel seçimlerinin kritik olarak tanımlanmasında siyasi, ekonomik ve sosyal unsurların etkisi nasıl analiz edilebilir? Çalışma boyunca her iki soru kritik yeniden saflaşma ve kritik seçim teorisi 1şı̆̆ında Türkiye'de 1999 ve 2002 genel seçimleri iç ve dış dinamikler çerçevesinde incelenecektir. Ardından GP'nin iyi oranda oy alması ve Ak Parti'nin iktidara gelişi konu kapsamında ele alınacaktır. Bu iki partinin seçilme nedenleri hem her iki partinin seçimlerden çok kısa süre önce örgütlenmiş olmaları ve seçim sonunda başarı elde etmeleridir hem de Ak Parti’nin günümüze kadar (2020) iktidarda kalmasıdır.

\section{KRITIKK YENIDEN SAFLAŞMA VE KRITIK SEÇIMM TEORİSI}

Kritik yeniden saflaşma ve kritik seçim teorisini analiz etmeye geçmeden önce kavram kargaşasının önüne geçmek gerekmektedir. Çalışmada hem kritik yeniden saflaşma hem de kritik seçim kavramı çoğu zaman birbirinin yerine geçecek şekilde kullanılmaktadır. Bunun nedeni, ilk olarak bu alanda çalışanların bazen iki kavramdan birini kullanmasından kaynaklanmaktadır. İkinci olarak ise kritik seçim olgusunu, seçmenlerin kritik yeniden saflaşması (ideolojik, ekonomik veya farklı sebeplerle) ortaya çıkarmaktadır. Kritik yeniden saflaşma ve kritik seçimlerin ortaya çıktığı seçimler, 20.yüzyılda sıklıkla rastlanılan "normal" seçimlerden farklılık gösterir. Bu seçim tipini normal seçimlerden ayıran en önemli faktör, parti sistemindeki mevcut durumun ani bir biçimde değişmesidir. Nitekim seçmenlerin alışagelmiş oldukları parti tercihlerini sürdürdükleri normal seçimler statükoyu yansıtırken; kritik seçimler, parti sisteminde uzun dönemli bir değişikliklere yol açar (Tosun, 2003, s. 28-32).

Cenap Nuhrat tarafından 1971 yılında yayınlanan Türkiye Köylerinde Olağandışı Oy Verme adlı çalışmada, köy halkının oy verme davranışlarını -"ilginç" olduğunu ifade ederek- araştırması önemlidir. Araştırmanın asıl amacı, köylerdeki oya katılma oranlarında, özel durumların birkaç seçim boyunca sürdürülüp, sürdürülmediğini incelemektir (1971, s. 220). Nuhrat araştırmasında, köylerdeki dışa kapalılık, çaresizlik, iş durumu (köye gelenler-köyden gidenler), nüfus oranları, Türkçe okuma yazma oranları (Şafi, Alevi-Caferi köylerinde), etnik aidiyet (Türk, Kürt köyleri) ve mülk sahibi olma durumu değişkenlerinden hareketle karşılaştırmalı bir analiz yapmıştır. Araştırmada, örneğin $\mathrm{HOV}$ (Hiç Oy Vermeyen) ve $D O K$ (Düşük Oy Kullanan) köylerin, yeni seçimlere katılmamasının gelip geçici, o ana mahsus bir protesto sonucunda değil, sürekli bir rahatsızlığın yansıması olduğu sonucu ortaya çıkmıştır. Hiç oy vermeme ya da düşük katılım sonrası, önceki seçimlerde çoğunluğu almış parti azınlığa düşerek, yerine başka bir parti denenmektedir. Öte yandan bu köylerde asıl rahatsılılı veren durum bir hizmetin yerine getirilmemesinden ziyade, "parlamenter düzen" karşısındaki ümitsizlikten doğan ilgisizliktir. TOV (Tüm oy kullanan seçmenlerin bir partiye ya da bağımsız adaya oy veren) köylerde ise iki unsur öne çıkmaktadır. Birincisi 'ekonomik güç'; ikincisi ise, 'aşiret bağları'dır. Aşiret bağlarının önemli olmasının sebebi, parti adayı kişinin çoğu zaman yerel egemen kişi (ağa) ile aynı olmasıdır. Böylece köy halkı seçim zamanlarda aynı kişiye oy vermektedir (1971, s. 232-236).

Nuhrat'ın araştırmasında ele aldığı değişkenler ve köy halkının siyasal, toplumsal, ekonomik koşullar ve beklentilere göre oy kullanmaya karar vermesi ya da oy kullanma konusunda düşük bir katılım sergilemesi önemlidir. Sonuçları itibariyle araştırmada "Olağandışı Oy Verme" kavramı bu çalışma 
açısından seçmenin yeniden saflaşmasına dair bulgular içermektedir. Böylelikle denilebilir ki seçmenin oy kullanma davranışı salt olarak seçme eyleminden ibaret değildir. Bir seçimin kendisi, birbirine bağlı bir önceki ve bir sonraki seçimlerde seçmenin, davranış akışında meydana gelen kolektif bir eylemdir. Demokratik düzenlerde seçimler arasında seçimlerin doğası, anlamı ve sonuçları bakımından çeşitli farklılıklar vardır. Tek bir millet içinde bile seçim gerçekliği zaman zaman büyük ölçüde farklılıklar gösterir. Dolayısıyla seçimlerde demokratik sürecin bir bütün olarak anlaşılması, seçmen davranışlarının farklılaşmasına -psikolojik olarak, kampanya bölünmeleri vs.- dayanır. Bu anlamda V.O. Key için bu açıklamalar bir seçim tipi kavramını formüle etme girişimi için -kapsamlı bir tipoloji geliştirme firsatı sunmasa da- bir yönelim sağlar (2014, s. 3). Böylece diğer bir makalesinde "Sürekli Yeniden Saflaşma" kavramını kullanan V. O. Key’e (1959, s. 198) göre, kısa süreli parti değişmelerinden farklı olan bu durumda seçmenler, uzun süreli ya da sürekli saf değiştirirler. Bu yüzden bazı seçimler geniş çaplı hareketler ve sürekli oy kaymaları nedeniyle kritik seçim olarak adlandırılabilir.

Evans ise yaptığı bir çalışmada seçimleri, değişimler açısından türlerine göre şu şekilde sınıflandırmıştır. Bu sınıflandırma, "Maintaining Elections (İktidarın değişmediği seçimler)", "Dealigning Elections (Seçmenlerin oy verdikleri partiye sadakatlerini yitirdikleri seçimler) ve "Realigning Elections (Yeniden saflaşmaların ve olduğu seçimler) şeklindedir (Evans, 1999, Aktaran: Robert ve Papp, 2012, s. 4). Bu çalışmada odaklanılan seçim türü yeniden saflaşma ve kritik seçimlerdir. Ancak öncesinde söz konusu sınıflandırmaları kısaca özetlemek gerekir. İktidarın değişmediği seçimler, toplumda yeni sorunların, bölünmelerin artmadığı ve seçmenlerin parti kimliklerinde önemli bir değişiklik gözlenemeyen statükoyu yansıtır. Yani bu seçimlerde oylar, parti blokları arasında büyük oranda yer değiştirmez. Oy verilen partiye sadakatin yitirildiği seçimlerde ise partiler ve seçmenleri arasındaki zayıflayan ilişki mevcut parti sistemini potansiyel olarak istikrarsızlaştırır. İktidar partisine oy verenler (Deviating Elections), hükümetin politika yapma konusundaki memnuniyetsizliklerinden dolayı rakip parti veya küçük, yeni ortaya çıkan partilere oy verirler. Bununla birlikte, oy verilen partiye duyulan memnuniyetsizlik her zaman uzun vadede parti kimliklerini değiştirmeyebilir. Parti sisteminde oluşan ani ve büyük değişikliklerin uzun vadeli etkilerine neden olan seçimler ise Kritik Yeniden Saflaşmalardır (Critical Realignment). Bu değişimler, ideolojik (sol-sağ bloklar arasında geçişler), sosyal (köklü değişim ve bölünmeler) ve partilerin kısa bir güçsüzleşme döneminden sonra yeniden tanımlandığı yeni partilerin ortaya çıkmasıdır (Robert ve Papp, 2012, s. 4-5).

Bu bağlamda, seçim dönemlerinde seçmenlerin süregiden (bloklar içi ve bloklar arasında) bir durumu ani ve uzun vadede değiştirecek bir biçimde yeniden saflaşmasını kritik olarak değerlendirebiliriz. Partilerin önceki seçimlere göre oylarının artmasındaki ya da azalmasındaki değişimi Özbudun, "Kritik Yeniden Saflaşma" (Critical Realignment) olgusuyla açıklamıştır. Özbudun'a göre bu olgu, "partinin seçmen tabanlarında radikal ve sürekli değişiklikleri içeren" olgudur (Özbudun, 2016, s. 42). Örneğin, Brezilya'daki 1944 seçimlerini inceleyen von Mettenheim yaptığı karşılaştırmalı çalışmada genel anlamda kritik seçimin ve yeniden saflaşmanın, sorunların velveya krizlerin ortaya çıkmasından ve büyük politika değişikliklerinden kaynaklandığını belirtir (von Mettenheim, 2009, s. 5). Darmofal ve Nardulli'nin Amerika Birleşik Devletleri'ndeki seçimleri analiz ettikleri The Dynamics of Critical Realignments: An Analysis Across Time and Space adlı makalede ele aldıkları kritik yeniden saflaşma nosyonu, yarım asırdan beri siyasetçilerin odağında kalmıştır. Bunun nedeni, olağan oy verme davranışının aksine, kritik yeniden saflaşmalarda seçmenler, partizan dengesinde çarpıcı ve kalıcı değişikliklere yol açan tutum ve davranışlarda bulunurlar (2010, s. 255). Evans ve Norris'in kaleme aldıklar1 A Critical Election? Understanding the 1997 British Election in Long-Term Perspective adl1 makalede ise, kritik seçimlerde büyük oylama bloklarının tıpkı Antarktika'daki buz kütleleri gibi gıcırdayıp, çatlayıp ve sonra yeniden birleştiğini ifade ederler. Kritik seçimler, parti desteğinin seçim temelinde daha kalıcı düzenlemelerle nitelendirilmiştir. Örneğin, bu düzenlemeler yeni seçmen gruplarını hedef alarak, stratejik olarak sol-sağ yelpazedeki ideolojik pozisyonları değiştirerek veya yeni liderler seçerek olabilir (2016, s. 1).

Özbudun ve Tachau, yaptıkları bir çalışmada Türkiye'de 14 Ekim 1975 genel seçimlerini analiz etmişlerdir. Yazarlara göre bu seçimler 'olağandışı' bir öneme sahiptir çünkü seçimler 12 Mart 1971 Askeri Muhtırası'nın ardından yapılmıştır. Seçimlerin diğer bir önemi ise, seçmen eğilimlerinin bir önceki seçimlere göre devam edip etmeyeceğine dair bir firsat sunmasıdır. Bu seçimlere Adalet Partisi 
(AP) Süleyman Demirel liderliğinde, CHP Bülent Ecevit liderliğinde, MHP Alparslan Türkeş liderliğinde ve Milli Selamet Partisi (MSP) ise Necmettin Erbakan liderliğinde katılmıştır. Seçimlerin sonucunda AP'nin galip geleceği beklenirken; sürpriz bir şekilde CHP-MHP galip gelmiş ve "koalisyon hükümeti” kurulmuştur. Çalışmalarında Burnham'ın "Kritik Yeniden Saflaşma” kavramını referans alan yazarlar, bölgesel kalıplar, (kentsel-kırsal farklılıklar ve sosyo-ekonomik kalıplar bağlamında) araştırmaları neticesinde seçim sonuçlarının bir dizi eğilimi gösterdiğine ulaşmışlardır. Seçim sonuçlarının sistematik analizi bu anlamda bir sürece işaret ederken; ekonomik baskı ve büyük partiler arasındaki ideolojik bölünmelerin seçmen davranışlarını etkileyebileceği anlaşılmaktadır. Örneğin, 1973 'te oy katılımı ile sosyo-ekonomik gelişme arasında pozitif bir korelasyon vardır. Bunun sebebi ise yazarlara göre, bahsi geçen yılların kutuplaşma ve ideolojik niteliğinin ortaya çıkması olabilir. Çünkü 1969 seçimlerine kıyasla daha fazla kent seçmeni oy kullanmıştır. İstanbul'da \%9.3'lük ve Ankara'da \%8.8'lik bir artış gözlenmiştir (Özbudun ve Tachau, 1975, s. 460-479). Tarihsel açıdan bakıldığında 20 Ekim 1991, 22 Aralık 1995 ve 18 Nisan 1999 genel seçimlerinde birinci olan parti değişirken; partilere yönelen seçmen tabanında büyük değişiklikler olmuştur. Dolayısıyla seçmenlerin oy davranışları ülkede meydana gelen iç ve diş dinamiklerin etkisiyle- farklı gerekçelerle değişebilmektedir. $\mathrm{Bu}$ çerçevede bir sonraki kısımda 1999-2002 tarihleri arasındaki süreçte Türkiye'nin iç ve dış dinamikleri incelenmiştir.

\section{9-2002 YILLARI ARASINDA TÜRKİYE'NİN İÇ VE DIŞ DİNAMÍKLERİ}

Türkiye'de 1999-2002 yılları arasında yaşanan toplumsal, siyasal ve ekonomik duruma dair iç ve dış dinamikler hem seçmenin oy verme davranışlarını çözümleyebilmek için önemlidir hem de kritik yeniden saflaşma ve kritik seçim teorisi açısından mühimdir. 1995 seçimlerinin ardından Refah Partisi $(\mathrm{RP})^{1}$, kurulan koalisyon hükümetinde yer almıştır. Partinin icraatları süresince Türkiye'de siyasi kutuplaşma ciddi boyutlara ulaşmış ve bu süreç Türkiye'yi 28 Şubat sürecine sürüklemiştir (Çarkoğlu ve Toprak, 2006, s. 15). DYP-RP koalisyon hükümetinin derin devlet yapılanmasının iç yüzünü aydınlatmada tatmin edici bir çaba göstermemesi ve RP'nin "İslam" ve "Muhafazakâr" kimliği, ülkede irtica tehdidi üzerinden siyasal ve toplumsal bir gerginlik yaratmıştır. 28 Şubattaki Milli Güvenlik Kurulu (MGK) kararları ile hükümeti kurma yetkisi ANAP Genel Başkanı Mesut Yılmaz'a verilmiştir. Sonraki süreçte "başörtüsü” konusu irtica tartışmalarının odağı olmuştur. Böylece başta üniversiteler olmak üzere bütün olarak kamusal alandan çıkarılması için sert tedbirler alınmıştır. Ayrıca İmam Hatip liselerinde okumak sıkıntılı bir durum olmaya başlamıştır. Bu okullardan mezun olanların sadece ilahiyat fakültelerine girmeleri kararı alınmıştır. Yüksek Öğrenim Kurulu (YÖK) tarafından ise İlahiyat Fakültelerinin kontenjanları kısıtlanmıştır (Çelik, 2017, s. 666-668). 28 Şubat sürecinden iki yıl sonra Çarkoğlu ve Toprak'ın yaptı̆̆ bir araştırmada sorulara verilen yanıtlar, "İslamc1-Laik" şeklindeki bölünmüşlüğü kanıtlamaktadır. Örneğin, araştırmadaki verilere göre, RP'ye inanlar ve inanmayanlar diye ikiye bölmüş olduğunu düşünenler ve bu fikre karşı çıkanlar \%37-\%40 oranında neredeyse eşittir (2006, s. 16).

Fiziki beka bağlamında bakıldığında bu dönem içinde yükselişe geçen terör ve komşular ile yaşanan sorunlar, ulusal güvenlik konusunda endişeye yol açmıştır. Nitekim Türkiye'nin bu dönem dış politikasını birinci derecede güvenlik kaygıları şekillendirmiştir (Şahin, 2014, s. 129). Nitekim 1998'de Türkiye ve Suriye arasında imzalan Adana Protokolü ile sınır güvenliği sağlanmış, aktörlerin tehdit algılayışları azalmış ve 1lımlı politikalar izlenmesine neden oluştur. Özellikle Hafız Esad'ın ölmesi ve onun yerine Beşer Esad'ın gelmesiyle beraber, Irak'taki siyasi konjonktüre bağlı olarak Kürt milliyetçisi hareketlerin canlanması ve ABD'nin bölgede kurmayı planladığı Kürt devleti projesi bölgede İran, Suriye ve Türkiye arasında ikili ilişkilerin geliştirilmesi açısından bir firsat olarak görülmüştür (Atlığlu, 2009, s. 78). Daha sonra Irak ile PKK terörü üzerinden başlayan gerilim ve 'güvenlikleştirme' politikalarının ön plana çıkmasına neden olmuş, kamuoyunda mevcut hükümete duyulan güven azalma eğilimi göstermiştir (Erdağ, 2013, s. 175-176). Bu güvenin azalmasında etkili olan diğer bir etken ise

${ }^{1}$ RP'nin 1995 seçimleri sonucunda koalisyon hükümetine katılması, Türk siyaset gözlemcilerini şaşırtmıştır. Aslında İslamcı bir zaferin ilk sinyalleri, RP adaylarının 27 Mart 1994 yerel seçimlerinde il belediyelerinin üçte birini almasıyla görülüyordu (Esmer, 2002, s. 93). 
Türkiye'nin AB'ye adaylık statüsünün açıklandığı Helsinki Bildirisi ve mevcut hükümetin tutumu ile ilgilidir. Özellikle Kürtlere yönelik kıstaslar, Abdullah Öcalan'ın mevcut durumu, Ege sorunları, Kıbrıs'in teritoryal durumu ve AB üyeliği ile ilgili sorunlar, fiziksel beka durumunu en çok zedeleyen unsurlar olmuştur. Helsinki Bildirisi'nde bu hususlara karşı dönemin DSP-MHP-ANAP Koalisyon Hükümeti, bazı çekinceler ile AB'nin verdiği adaylık kararını kabul etmiştir (Taner-Özkeçeci, 2012, s. 12). Fiziksel bekayı zedeleyen bu adımların Bülent Ecevit tarafından 4 Haziran 1999 yılında TBMM'de açıklanan 57. Hükümet programıyla da çeliştiği görülmektedir. ${ }^{2}$

Abdullah Öcalan'ın 15 Şubat 1999'da Türkiye'ye getirilerek hapsedilmesinin ardından, 1999 genel seçimlerinde Bülent Ecevit halkın desteğini almıştır. Türkiye'de terör faaliyetlerinden sorumlu örgüt liderinin yakalanması, Türk siyasal hayatı için önemlidir. Çünkü seçim sürecinde "milliyetçi" ve "devletçi” söylemler ön plana çıkmış, milliyetçi-muhafazakâr bir parti olan Milliyetçi Hareket Partisinin (MHP) tarihteki en fazla oyu almasını sağlamıştır. Bu anlamda 28 Şubat süreci seçimlerden sonra da etkilerini göstermiştir. MHP-ANAP hükümeti kurulurken, RP'nin devamı olan FP ve 28 Şubat sürecinde RP'nin ortağı DYP'nin komisyonda olamayacağ 1 propagandaları yapılmıştır. Meclise FP listesinden giren Merve Kavakçı'nın türbanıyla Meclise girmesi DSP milletvekilleri tarafindan protesto edilmiştir. Dahası üniversitelerde türbanlı öğrencilere yönelik tacizler artmış ve Ahmet Taner Kışlalı gibi şahsiyetlerin suikastları da kaos ortamına zemin oluşturmuştur (Çelik, 2017, s. 671-673).

28 Şubat süreci ve ardından uygulanan kararlarda dışlanmış İslam-Muhafazakâr kimliğinin yanında milliyetçi söylemlerin ön planda olduğu siyasi anlamda karmaşık bir ortam vardır. Böylesi kaotik bir ortamda, 17 Ağustos 1999'da meydana gelen Gölcük Depremi toplum nezdinde travmatik ${ }^{3}$ bir etki yaratmıştır. Depremde yaşanılan ciddi can kayıplarının yanında, afetin yol açtığı yıkımların hükümetin ekonomik performansını etkilemesi kaçınılmaz olmuştur. Ekonomik aktivitelerin fazla olduğu yedi ilde (Kocaeli, Sakarya, Yalova, İstanbul, Bolu, Bursa, Eskişehir) yıkımın boyutları ciddi seviyede iken; deprem ağırlıklı olarak karayolu, demiryolu, haberleşme ve enerji dağıtım tesislerine de zarar vermiştir. İmalat sektörünün yoğun olduğu yerlerdeki hasarlar nedeniyle üretim, ihracat ve ithalat kayb1 yaşanmıştır. Turizm sektöründe yaşanan kayıp (173 milyon dolar) önemli boyutlarda olmuştur. Hastanelerin hasar görmesi, deprem sonrasında gereken yardımların depremzedelere ulaşmasını engellemiştir (Aktürk ve Albeni, 2002, s. 4-9). Depremin olduğu yıllar, Türkiye ekonomisinde üretimin daraldığı, ihracatın ve ithalatın azaldığı, bütçe açı̆̆ı ve iç borçların ve enflasyonun arttığı; kısaca, ekonominin zor durumda olduğu bir dönemdir (Aktürk ve Albeni, 2002, s. 12). Dolayısıyla depremin yol açtığı kayıplar ve travmalar, ekonomiyi zor durumda bırakırken; hükümeti de zor durumda bırakmıştır.

10-11 Aralık 1999 tarihinde yapılan Helsinki Zirvesi'nde Türkiye'nin Avrupa Birliği'ne (AB) adaylığının ilanı ile Türkiye-AB ilişkilerinde yeni bir aşamaya geçilmiştir. AB Konseyi'nin Binyıl Bildirgesi'nde Türkiye'nin aday üyeliği tüm dünyaya ilan edilmiştir. Ardından hükümet, 28 Şubat Kararları ve AB'nin tam üyelik koşulları için öne sürdüğü yasal düzenlemeleri yerine getirebilmek için çalışmalarını artırmıştır (Çelik, 2017, s. 673; Sayın, 2016, s. 43-45). Türkiye'nin dış ticaret politikaları 1994'ten sonra AB ile imzalanan Gümrük Birliği Antlaşması'na bağımlı kılınmış, sadece AB değil üçüncü ülkelere de uygulanan gümrük tarifeleri ve tarife dışı engeller de artık Brüksel'de belirlenmeye başlanmıştır (Akşin, Tanör ve Boratav, 2008, Aktaran; Yüce, 2012, s. 207). Bu minvalde AB ve Uluslararası Para Fonu (IMF) ile olan ilişkiler ve borçlanma konusu kamuoyu nezdinde 57. Hükümetin başarısızlığı olarak değerlendirilmiştir. Nitekim bu durum "yapısal reformların gerçekleştirilmesinde gecikmelere neden olmuş ve IMF, yapısal reformlardaki gecikmeleri öne sürerek programın üçüncü

\footnotetext{
${ }^{2}$ Bülent Ecevit "her türlü teröre karşı devlet güvenlik güçlerinin özverili ve başarılı mücadelesi, kesin sonuç alınıncaya kadar kararlılıkla sürdürülecek, diğer taraftan da, terörün iç ve dış kaynaklarını kurutacak tedbirler alınacaktır. Ayrıca ekonomik, sosyal, siyasal, eğitsel ve tanıtımla ilgili çok yönlü tedbirler alınacaktır. Güneydoğu ve Doğu Anadolu'nun geri kalmışlı̆ı, ekonomik ve sosyal önlemlerle çözülecektir; işsizliği ve yoksulluğu önleyici üretken yatırımlar hızlandırılıp, desteklenecektir. 11 Mayıs 2020 tarihinde https://www.tbmm.gov.tr/tutanaklar/TUTANAK/TBMM/d21/c001/tbmm21001011.pdf adresinden erişildi.

${ }^{3}$ Marmara depremi sonrası ruhsal travma ve toplum ruh sağlığı politikaları konusunda ayrıntılı bilgi için bakınız. Tamer Aker (2006). 1999 Marmara depremleri: epidemiyolojik bulgular ve toplum ruh sağlığı uygulamaları üzerine bir gözden geçirme. Türk Psikiyatri Dergisi, 17(3). 204-212.
} 
kredi dilimini ertelemiştir" (Keskin, Kiriş ve Şentürk, 2006, s. 52). Koalisyon Hükümeti’nin (DSP ve ANAP) IMF'ye gönderdiği niyet mektubuna, MHP’nin ekonomik ilkelerine aykırı olmasına rağmen destek vermiştir. Kararın uygulanması sorunlu olunca, hükümet kısmen dağılsa da, MHP bu dönemde hükümetten ayrılma tehdidinde dahi bulunmamıştır (Taner, 2012, s. 8). Nihai olarak DSP-MHP-ANAP hükümeti arasında ideolojik ve yapısal farklılıklar ekonomik bağlamda tutarlı ve net kararlar alınmasına engel olmuş, piyasalarda mevcut sisteme karşı güvensizlik artış göstermiştir. Piyasaların mevcut hükümete olan güven kaybı 2001 küresel ekonomik krizinin de etkisi ile 2001-2002 yılları arasında GSYH'de \%5.7, sanayi üretimlerinde \%8.7, yatırımların ise \%30 azalmasına neden olmuştur (Macovei, 2009 , s. 6). Aynı zamanda iç piyasada, enflasyon oranın \%40'a çıkması, dolarda \%25, markta \%12'lik artış 2002 itibari ile Ak Parti ve diğer partilerin seçimlerde kullandığ 1 temel argümanlar olmuştur (Keskin, Kiriş ve Şentürk, 2006, s. 54). Dolayısıyla 1998-2001 yılları arasında dünya ekonomisi Doğu Asya'dan başlayıp, Doğu-Avrupa, Latin Amerika ekonomilerini etkileyen bir dizi finansal kriz yaşamış ve Türkiye de bu krizlerden oldukça etkilenmiştir (Boratav, 2011, s. 193).

Ekonominin seçmen davranışı üzerindeki etkisi Yasushi Hazama'nın Geriye Dönük Oy Kullanma Modeli (Retrospective Voting) ile incelenebilir. Bu model, bireylerin oy kullanmaya karar verirken sosyo-ekonomik kazanımlarını değerlendirdiğini varsayar. Hazama, Türkiye'de bireysel anket yöntemiyle yaptığı çalışmada geriye dönük oy kullanmaya ilişkin iki ana soruyu incelemiştir. İlki, seçmen kararlarının hane halkı ekonomisi koşullarına, ulusal ekonomi koşullarına veya diğer sosyopolitik koşullara dayanıp dayanmadığıdır. İkincisi, ekonominin gelecekteki yani öngörülen ekonomi değerlendirmesinin, geçmiş değerlendirmelerin dışında seçmen kararlarını etkileyip etkilemediğidir. Hazama'nın ulaştığı verilere göre, hane halkı ekonomisi, ulusal ekonomi ve toplumsal politikaların değerlendirilmesi, -aralarında karşılıklı bir korelasyon olup olmadığına bakılmaksızın- seçmen desteğinin önemli bir belirleyicisidir. Geçmişin değerlendirilmesi konusu ise hane halkı ekonomisi ve sosyo-politik koşullar için geleceğin değerlendirilmesinden daha önemli olduğu anlaşılmıştır. Genel anlamda seçmenler geriye dönük oylama için kişisel ekonomilerini (kazanımlarını) dikkate alırken; ileriye dönük oylama için (Prospective Voting) ulusal ekonomiyi dikkate almaktadır (Hazama, 2006, s. 15-16).

Türkiye'de, 2002 seçimlerinde beklenmedik bir sonucun ortaya çıkmasında önceki yıllardaki (19981999 ve 2001) ekonomide finansal krizlerinin etkisi, Geriye Dönük Oy Kullanma Modeli ile açıklanabilir. O halde kırılgan ulusal ekonomi, hane halkı ekonomisini ne yönde etkilemiştir? 24 Ocak 1980 Kararları ile birlikte serbest piyasa ekonomisine angaje olan Türkiye'nin ilk hedefi dışa açılma iken; ikinci hedefi enflasyonun düşürülmesi olmuştur. 2000 yılının ilk yarısında ise faiz oranları aşağı çekilince, küçük bankalar büyük bankalar ile rekabet edememiş ve likitide krizine yol açmıştır (Firat, 2009, s. 503-511). 15 Nisan 2001 yılında Kemal Derviş'in öncülügünde “Güçlü Ekonomiye Geçiş Programı" (GEGP) ile IMF destekli istikrar programı uygulanmıştır. Programın amacı, ekonomide bunalımı ve istikrarsızlığı ortadan kaldırmak ve kamu yönetiminin ve ekonominin yeniden yapılandırılması ${ }^{4}$ adına bir alt yapı oluşturmaktır. "Eski düzene dönmek artık gerçekten mümkün değildir." ibaresiyle birlikte öngörülen hedeflere ulaşılması için kesin bir "siyasi" taahhüttün ve desteğin olduğunun altı çizilmiştir (Türkiye'nin Güçlü Ekonomiye Geçiş Programı, 2001).

Bu bağlamda, program çerçevesinde bir kurumun yeniden yapılandırılması, öncelikle "bu kurumlardaki personelin azaltılması (bazen aşamalı olarak işten çıkarma yöntemi ile istihdam azaltılır bazen de emekliliğe teşvik gibi yöntemlere başvurulur) anlamına gelir; daha sonra ise kurumsal değişikliklere gidilmesi (örneğin bir Kamu İktisadi Teşebbüsleri'nin yeniden yapılandırılmasında bu aşamada KIT'in şirketleştirilmesi gerçekleştirilir) anlamına gelir." 2000 yılında tütün, şeker pancarı gibi ürünlere hükümet sübvansiyonları kesilirken; çiftçileri bu ürünlerden vazgeçirmek amacıyla "Doğrudan Gelir Sistemi" devreye sokulmuştur. Sosyal güvenlik alanında ise, yeniden yapılandırma kapsamında

${ }^{4}$ IMF ile 1999'da imzalanan istikrar programında tarım, sosyal güvenlik, kamu mali yönetimi ve vergi politikası ve idaresi alanlarında yapısal reform öngörülmüştür. IMF programına sektörel krediler sağlayan Dünya Bankası (DB), yönetişim modelinin Türkiye'de inşa edilmesinde önemli bir ortak olmuştur. Dolayısıyla Türkiye'de destek gören yönetişimin inşa sürecinde dış dinamiklerin etkisi büyüktür (Bayramoğlu, 2014, s. 292-293). 
emeklilik yaşı yükseltilmiş ve devlet eliyle özel emekliliğin desteklenmesi bir kamu politikası olarak benimsenmiştir. Dolayısıyla neoliberal politikalar, yönetişim modelini kanunlarla güvence altına alarak kurumlaşmış bir dönüşüm sürecidir. Öte yandan bu çerçevedeki özelleştirme politikası ise devletin ve toplumun piyasalaştırılmasında sadece bir araç olmuştur (Bayramoğlu, 2014, s. 292-293). Türk Mühendis ve Mimar Odaları Birliği'nin (TMMOB), GEGP üzerine yaptığı değerlendirme toplum üzerindeki ekonomik baskıyı ifade etmektedir,

\begin{abstract}
“GEGP'ye göre 'eski düzene' dönmek artık mümkün değildir. Program, siyaset ve ekonomi alanlarının ayrlması temelinde, devletin fonksiyonlarının esas itibariyle 'denetim' ve 'eğitim, sağllk ve adalet' gibi kamu hizmetleri ile sinırlanacă̆ bir düzeni hedeflediği iddiasındadır. İnsanca bir yaşam için eğitim, să̆lık ve diğer kamu hizmetlerinin iyileştirilmesi gerektiğine kuşku yoktur. Ancak önerilen program bu temel ihtiyaçların 'daha iyi' karşılanmasını gerçekleştirmek bir yana, toplumsal eşitsizlikleri daha da arttırarak, mevcut toplumsal ve ekonomik sorunları derinleştirecektir" (TMMOB, 2001, s. 7).
\end{abstract}

Diğer yandan önemli dinamiklerden biri de "kimlik" meselesidir. Öyle ki kimlik kendini tanımlamada ve öteki ile arasındaki farklılığı vurgulamada ve kimliğin gerektirdiği şekilde hareket etmede önemli bir kavramdır (Wendt, 2016, s. 294). Dahası kimlik çıkarların belirlenmesi sürecini de ortaya koymaktadır (Wendt, 1992, s. 398). Koalisyon hükümetlerinin (1999-2002) benimsemiş olduğu kimlik ve bunun bir yansıması olan ulusal çıkarları gerçekleştirmedeki başarısızlığı, kamuoyu tarafından eleştirilmiş ve seçmen davranışlarını etkilemiştir. Ulusal çıkarlar özerklik, ekonomik refah, kolektif özsaygı, fiziki bek ihtiyaçlarından doğmaktadır. Bu ihtiyaçlar toplum nezdinde karşılanmamış, iktidara duyulan güven de azalmaya başlamıştır. Nitekim Wendt'e (1992, s. 293-295) göre, "bu dört ihtiyacın (ulusal çıkarların) karşılanmadığı durumda devletler genellikle yok olmaktadır." Uluslararası sistemin yapısının Soğuk Savaş sonrası değişmesi ile Türkiye devlet kimliği anlayışında farklılıklar meydana gelmiştir. $\mathrm{Bu}$ doğrultuda siyasi partiler ve hükümet modelleri ile bağlantılı olarak Avrasyacılık, İslamcılık, NeoOsmanlıcılık gibi kimliklerin benimsendiği görülmektedir. Bu nedenle Ak Parti'nin iktidara gelmesinden önceki dönem içinde benimsenen devlet kimliğinin gelişimi ve iç politikada tezahürünün büyük etkisinin olduğu görülmektedir.

1999-2002 yılları arasındaki süreçte siyasi, toplumsal, psikolojik ve ekonomik gelişmeler seçmenlerin oy verme davranışını etkilemiştir ve bu yönelimde şimdiye kadar üzerinde durulan iç ve diş dinamiklerin büyük ölçüde etkisi olmuş, seçim sonucunda tek parti hükümeti kurulmuştur. Bölgede ve uluslararası alanda koalisyon hükümetinin yaşadığı itibar kaybı, 2002 genel seçimlerinde etkili olmuştur. Özellikle AB'nin Avrupa Güvenlik ve Savunma Kimliği (AGSK) ile Kuzey Atlantik Antlaşması Örgütü'nün (NATO) imkân kabiliyetlerini kullanabilme durumu karşısında, mevcut hükümetin veto yetkisini kullanacağını söylemesi, sonrasında bu kararından vazgeçmesi, koalisyon hükümetine olan güveni zedelemiştir (Çayhan, 2002, s. 53-54). Ekonomik ve siyasi sorunların artmasının sosyal alanda yansıması ise bir esnafın başbakanlık binasının önünde Ecevit'e yazar kasa firlatmasıyla sembolize edildiği görülmektedir (Yıldırım, 2010, s. 115). Bu gelişmeler sosyal alanda güçlü lider söylemlerini tetiklemiş ve seçimlerde, Ak Parti'de Recep Tayyip Erdoğan'ın ve GP'de Cem Uzan'ın liderlik ettiği Türkiye'de siyasal hayatında karizmatik liderlik ${ }^{5}$ olgusunun tepeye tırmandığ 1 döneme girilmiştir (Kavak, 2017, s. 71). Nitekim kriz ortamında güçlü lider söyleminin seçmen nezdinde olumlu karşılandığı görülmektedir. 


\section{KASIM 2002 KRITIK SEÇIMLERI: GP'NIN YÜKSELISȘi VE AK PARTI'NIN İKTIDARA GELIŞi}

\section{Genel Hatlarıly 1999 ve 20002 Genel Seçimleri}

1999 genel seçimlerinde Türkiye geneli seçmen sayıs1 37.495.217, oy kullanan seçmen sayısı 32.656.070 iken; katılım oranı \%87.1'dur. Seçim sonrası homojen bir sonuç ortaya çıkmamış; koalisyon hükümeti kurulmuştur. 2002 genel seçimlerinde ise, Türkiye geneli seçmen sayısı 41.407.161, oy kullanan seçmen sayısı 32.768.161 iken; katılım oranı önceki seçimlere göre düşerek \%79.14 oranında kalmıştır. Her iki seçimde de seçim baraj1 \%10 olarak belirlenmiştir.

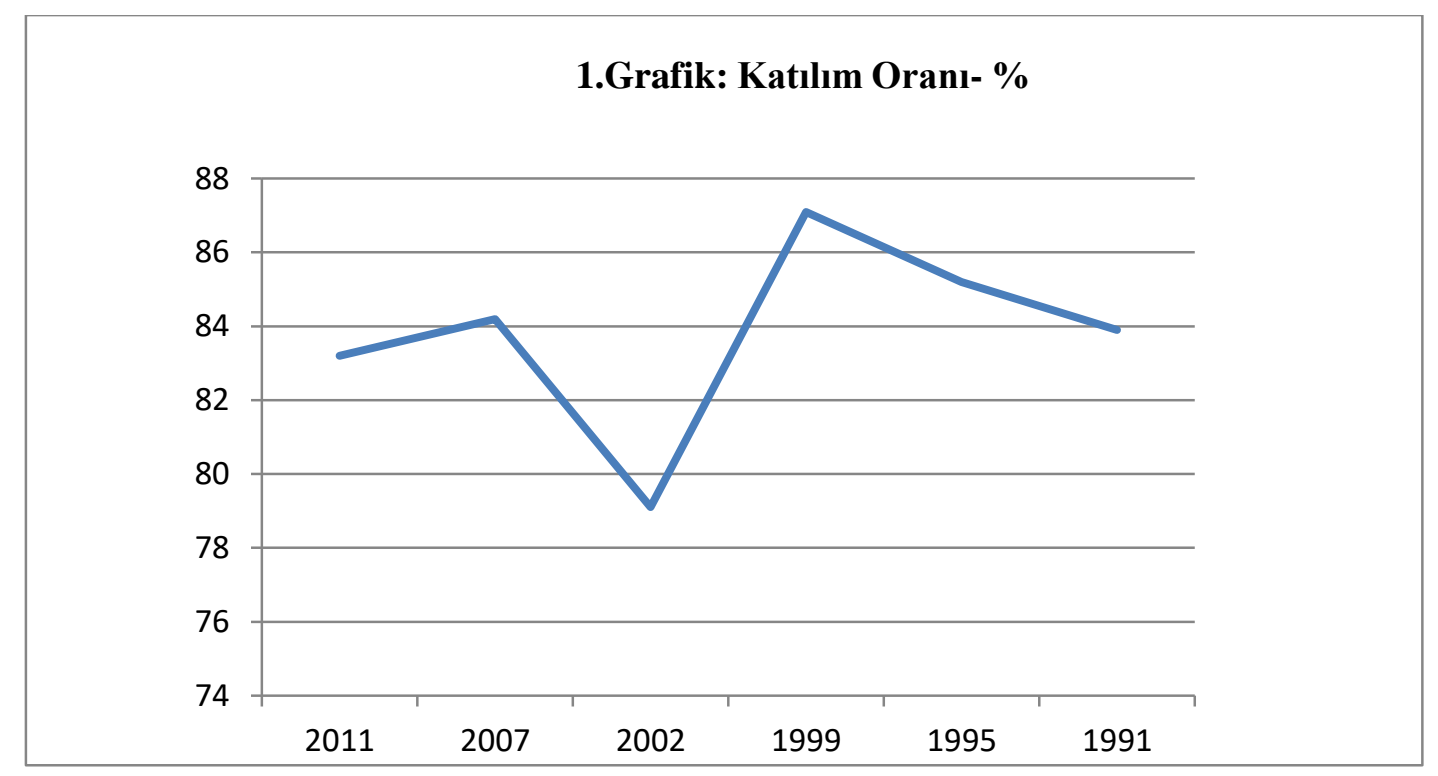

Kaynak: TÜİK verilerine aittir.

Grafikte altı yıla ait seçimlere katılım oranlarından anlaşılacağı üzere 18 Nisan 1999 seçimlerinde oy kullanan seçmen sayısı oranı 2002 seçimlerinde gözle görülür bir farkla düşmüştür. Nitekim bu seçimlerde, seçmenlerin \%21'nin oy kullanmadığ 1 anlaşılmaktadır. Türkiye geneli seçmen sayısının 2002 yılında artış göstermesine rağmen, bir önceki seçimlere göre oy oranında \% 7.9'luk bir puan düşüşü yaşanmıştır. Bu noktada Nuhrat'ın çalışmasındaki bulguları hatırlamak gerekir, " $\mathrm{HOV}$ (Hiç $\mathrm{Oy}$ Vermeyen) ve DOK (Düşük Oy Kullanan) köylerin, yeni seçimlere katılmamasının gelip geçici, o ana mahsus bir protesto sonucunda değil, sürekli bir rahatsızlı̆̆ı yansıması olduğu sonucu ortaya çıkmıştır. Hiç oy vermeme ya da düşük katılım sonrası, önceki seçimlerde çoğunluğu almış parti azınlı̆̆a düşerek, yerine başka bir parti denenmektedir" (1971, s. 232-236).

1.Tabloda 2002 genel seçimlerinde oy kullanmayıp; 1999 genel seçimlerinde seçmenlerin (araştırma grubunun) tercih ettikleri partiler yer almaktadır. Buna göre seçmenler artık siyasetçilere güvenmemeleri, seçimlerin önemli bir değişiklik yaratacağına inanmamaları, partilerin vaatlerini gerçekleştirmemiş olmaları ve liderlere güvenmemeleri gibi sebeplerle oy kullanmamışlardır. Seçmenler için çözülmesi gerek en önemli sorunlar ise ekonomik kriz (\%72), işsizlik, AB ile ilişkiler, demokratikleşme ve insan hakları sorunları olmuştur. Seçmenlerin \%40.2 gibi büyük bir oranı ilk sırada yer alan Ak Parti'nin bu sorunları çözeceğini ifade ederken; \%2.3 gibi bir puanla GP beşinci sırada yer almıştır (Gökçe, Akgün ve Karaçor, 2002, s. 21-23). 
Tablo 1. 3 Kasım 2002'de Oy Vermeyenlerin 1999'daki Parti Tercihleri

\begin{tabular}{|l|c|}
\hline 1999'da hangi partiye oy verdiler? & \% \\
\hline 1999'da oy kullanmayanlar & 35.0 \\
\hline 1999' da seçmen olmayanlar & 15.0 \\
\hline 1999'da MHP'ye oy verenler & 9.1 \\
\hline 1999'da DSP'ye oy verenler & 8.9 \\
\hline 1999'da ANAP'a ye oy verenler & 5.2 \\
\hline 1999'da DYP'ye oy verenler & 3.2 \\
\hline 1999'da CHP'ye oy verenler & 2.7 \\
\hline 1999'da FP'ye oy verenler & 1.4 \\
\hline 1999'da HADEP'e oy verenler & 1.4 \\
\hline Hat1rlamiyor & 6.1 \\
\hline
\end{tabular}

Kaynak: Gökçe, Akgün ve Karaçor'un 2002 yılında yayınlamış olduğu 3 Kasım Seçimleri'nin Anatomisi: Türk Siyasetinde Süreklilik ve Değişim isimli çalışmadan yararlanılmıştır.

2002 genel seçimlerinde seçmenin oy katılımının azalması ve seçimlerin beklenmedik bir şekilde sonuçlanmasıyla söz konusu bulguların geçerli olduğu anlaşılmaktadır. Öyle ki bir önceki seçimlerde iktidarda olan partiler baraj altında kalarak azınlığa düşmüş ve elli yıl sonra radikal bir değişiklik ile yeni bir parti tek başına iktidara gelmiştir. 2. tabloda partilerin aldıkları oy oranlarına bakıldığında partilerin seçmen tabanlarındaki oy kayması anlaşılabilir. Dolayısıyla 2002 genel seçimlerinde seçmenler, bir önceki seçimlerde oy verdikleri partiler dışında bir başka partiye oy vermeyi tercih etmişlerdir. Temsilde adalet yönetimde istikrar minvalinde analiz edildiğinde ise oyların $\% 45$ gibi büyük oranının mecliste temsil edilmediği anlaşılmaktadır. Bunun sebebi ise 12 Eylül 1980 askeri darbesi sonrasında, yönetimde istikrar sağlanması amacıyla seçim barajının $\% 10$ olarak belirlenmesidir.

Tablo 2. 1999 ve 2002 Genel Seçimlerinde Oy Oranları ve Milletvekili Saylları

\begin{tabular}{|l|c|c|c|c|c|}
\hline $\begin{array}{l}\text { Siyasi Parti } \\
\text { İsimleri }\end{array}$ & $\begin{array}{l}\text { 1999 Genel } \\
\text { Seçimlerinde } \\
\text { Oy Oran1-\% }\end{array}$ & $\begin{array}{l}\text { 2002 Genel } \\
\text { Seçimlerinde } \\
\text { Oy Oran1-\% }\end{array}$ & $\begin{array}{l}\text { 1999 Genel } \\
\text { Seçimlerindeki } \\
\text { Milletvekili } \\
\text { Say1s1 }\end{array}$ & $\begin{array}{l}\text { 2002 Genel } \\
\text { Seçimlerindeki } \\
\text { Milletvekili } \\
\text { Say1s1 }\end{array}$ & $\begin{array}{l}\text { Oy } \\
\text { Fark1*** }\end{array}$ \\
\hline DSP & 22.2 & 1.2 & 136 & - & -21 \\
\hline MHP & 18.0 & 8.3 & 129 & - & -9.7 \\
\hline FP* & 15.4 & 2.5 & 111 & - & -12.9 \\
\hline ANAP & 13.2 & 5.1 & 86 & - & -8.1 \\
\hline DYP & 12.0 & 9.6 & 85 & - & -2.4 \\
\hline CHP & 8.7 & 19.4 & - & 178 & +10.7 \\
\hline HADEP** & 4.7 & 6.2 & - & - & +1.5 \\
\hline BBP & 1.4 & 1.0 & - & - & -0.4 \\
\hline BAĞIMSIZLAR & .88 & 1.0 & 3 & 9 & +.12 \\
\hline AK PARTI & - & 34.3 & - & 363 & 34.3 \\
\hline GP & - & 7.2 & - & - & 7.2 \\
\hline YTP & - & 1.0 & - & - & +1.0 \\
\hline
\end{tabular}

Kaynak: Gökçe, Akgün ve Karaçor'un 2002 yılında yayınlamış olduğu 3 Kasım Seçimleri'nin Anatomisi: Türk Siyasetinde Süreklilik ve Değişim isimli çalışmadan ve TÜİK verilerinden yararlanılmış̦tır.

*FP, 2002 genel seçimlerine Saadet Partisi ismiyle katılmıştır.

**HADEP, 2002 genel seçimlerine DEHAP ismiyle katılmıştır.

***Oy farkı, iki seçimin oy oranlarının çıkarılması ile elde edilmiştir.

1999 genel seçimlerinde hiçbir parti tek başına hükümeti kuracak yeterli oy çoğunluğunu alamamıştır. Bir önceki seçimlerde baraja takılan Deniz Baykal liderliğindeki CHP, iktidara hazırlanırken ana muhalefet partisi görevini üstlenen ve en çok oy olan ikinci parti olmuştur. Ayrıca 9 bağımsız 
milletvekili meclise girmeyi başarırken; en dramatik oy kaybını \%21'lik bir puan düşüşü ile DSP yaşamıştır. DSP'nin ikiye bölünmesi, Bülent Ecevit'in sağlık durumunun kötü olmasına rağmen iktidarı bırakmaması ve ekonomik krizin derinleşmesi söz konusu puan düşüşünün nedenlerindendir. Öte yandan seçimlerde vatandaşın sorunları ile ilgilenmeyen MHP de yenilgiye uğramıştır. Bir önceki seçimlerde ikinci parti olan MHP, \%10'luk bir puan kaybı yaşamıştır. ANAP da benzer nedenlerden dolayı meclise girememiştir (Gökçe, Akgün ve Karaçor, 2002, s. 2-3). 3 Kasım 2002'de sandığa yansıyan oy oranları, seçmenlerin oy verme tercihlerindeki değişimi ifade etmektedir

FP’nin bölünmesiyle ortaya çıkan Saadet Partisi meclise giremezken; bu partiden ayrılan (Yenilikçiler) Ak Parti en fazla milletvekili sayısı ile iktidara gelmiş ve tek parti hükümetini kurmuştur. Bu noktada yeni bir oluşum olan GP'nin aldığı oy oranı oldukça önemlidir. GP oyların \%7.2'sini alarak yükselişe geçmiştir. Partinin önemi ise, Ak Parti gibi yeni bir oluşum olması ve siyasi, ekonomik ve sosyal anlamda seçmende umut yaratmasıdır. Zira kamuoyunun, sorunların çözülmesi ve krizlerin aşılması için iktidardaki koalisyon partisine olan güveni azalmıştır. 'Ezber Bozan Seçimler' başlığıyla Bianet’te yer alan değerlendirmeye göre, "Orhan Gökçe, Birol Akgün ve Süleyman Karaçor tarafindan yapılan araştırma seçmenlerin yüzde \%54'ünün daha önceki seçimlerde oy verdiği partiyi değiştirdiğini, 3 Kasım 2002 seçimlerinde başka bir partiye oy verdiğini gösteriyor" ifadesi, partiler arası oy oynaklığının bir ifadesidir (İpekşen ve Duman, Bianet, 26 Mayıs 2015; Gökçe, Akgün ve Karaçor, 2002, s. 4).

\section{Genç Parti’nin Yükselişi ve Ak Parti’nin İktidara Gelişi}

Uzan Grubu' 'nun 46. Yll Kutlamaları'ndan GP'nin yeniden örgütlendiği 10 Temmuz $2002^{7}$ tarihlerinde Türkiye'de gündem, erken seçim tartışmalarıdır. Bülent Ecevit'in hastalığı nedeniyle yaşanan 'yönetim krizi', faiz oranlarının yükselmesi, ekonomik sıkıntılar ve AB'ye uyum politikaları da tartışma konularındandır. Cem Uzan'ın GP'yi kurduğunu ilan ettiği ilk konuşması birçok televizyon kanalında aynı anda yayınlanmıştır. Giriş konuşmasında ise gençlere, üniversiteyi kazanamayanlara, işsizlere; kısaca Türkiye'de umutsuz, huzursuz ve güvensiz seçmenlere seslenmiştir (Türk, 2007, s. 61-63). "İște hayal gücünü zorlayan seçim vaatleri”, "Tarihin en iddialı seçim vaatleri” başlıklarıyla gündeme gelen GP Genel Başkanı Cem Uzan'ın vaatleri arasında, “Her işsize 350 TL maaş verilecek. Mazot 1 TL olacak. Fındık 8 TL olacak. Üniversite sinavı kalkacak. Üniversite sayısı 4 katına çıkarılacak ve daha niceleri..." gibi popülist söylemler ön planda olmuştur (CNN Türk 17 Aralık 2014). Nitekim GP'nin seçim sloganı, bu söylemlerle örtüşecek bir biçimde "ÖSS kalkacak", "Mazot 1 Lira olacak" şeklindedir (CNN Türk 10 Temmuz 2014).

İş insanı Cem Uzan tarafindan kurulan GP'nin söylemleri analiz edildiğinde, bir önceki hükümetten memnuniyetsiz toplumun desteği anlaşllabilir. Üç ay gibi kısa bir sürede örgütlenen GP, öncelikle neredeyse her şehirde mitingler düzenlemiştir. 12 Ağustos 2002 tarihinde başlayan bu mitinglerde doğrudan halkın sorunlarına yönelik çözümler içeren vaatlerde bulunmuştur. Dahası halkın mitinglere katılımını artırmak için de tanınmış ünlülerin yer aldığı konserler düzenlemiştir. Televizyon, gazete ve radyo kanalları gibi iletişim mecralarını da kullanarak parti propagandası yapmıştır. GP'nin kampanyası, konserli ve ikramlı mitingleri, genç ve yakışıklı iş insanı Cem Uzan'ın pazarlama faaliyetleri ile aldığı \%7.2 gibi bir oy oranına erişmesi çarpıcı olarak değerlendirilmiştir (Bora, 2002). GP'nin uyguladığı siyasette "pazarlama" faaliyetlerinin kazanımları, seçim sonuçlarına bakıldığında anlaşılabilir (Akkılıç, İlban ve Özbek, s. 222). Seçim kampanyalarında başarılı bir strateji izleyen Cem Uzan, seçmen kitlesine, kendisine ve partisine yönelik bilgileri Star Gazetesi gibi iletişim mecralarında tekrar tekrar sunmuştur. Görsel iletişim de ise halk ile iç içe (çiçek alırken, halkı selamlarken, çocukları severken, camide dua ederken gibi) olduğu fotoğraflar sunulmuştur. Hatta mitinglerinde insanlarla yan yana poloroid fotoğraflar çektirmiştir (Yalnız, 2004, s. 63-65). Yeni Şafak Gazetesi'nde yer alan Mehmet Barlas'ın

${ }^{6}$ Uzan Grubu'nun yükselişi Türkiye'de dönemin siyasal, sosyal ve ekonomik yapısından bağımsız değildir. Bu dönemde 'karma ekonomi' anlayışı mevcuttu ve bu anlayışa göre devlet, özel sektörü desteklemekteydi. Uzan Grubu medya, telekomünikasyon, yap1 grubu, enerji grubu, spor grubu gibi çeşitli mecralarda şirketlere sahipti (Türk, 2007, s. 21-22).

${ }^{7}$ Genç Parti ilk olarak 26 Kasım 1992'de kurulmuştur. Ardından parti kendi feshederek Yeniden Doğuş Partisi'ne (YDP) katılmıştır. 
köşe yazısı, GP'nin seçim propagandaları ve beklenen seçim sonuçlarının niteliğini şu şekilde ifade etmektedir,

"Yeni Çă̆’ın bütün iletişim ve ulaşım araçlarını kullanıyor Cem Uzan... Uçak mı, helikopter mi, televizyon mu, radyo mu, GSM telefon sistemi mi? Hepsi devrede... Ve ayn günde, 3-4 kenti ziyaret ediyor Cem Uzan... Otobüsün üzerinden konuşuyor... Sonra halkın arasına iniyor ve mümkün olduğunca, kendisini dinleyenlerle el slkışlyor... Cem Uzan'ın konuşmalarına kulak verin... Ne diyor? -Bütün vergiler inecek... KDV, gıda maddelerinde sifirlanacak... Illacın, serumun, kanın KDV'si inecek... Üniversiteye giriş sinavi kalkacak... Ders kitapları öğrencilere bedava dağıtılacak. Önceki gün Bilecik ve Kütahya'daydı Cem Uzan... Dün de Burdur, Isparta, Denizli kentlerinde, halka bunlart söyledi... Mesut Yılmaz özel uçakla Brüksel'e gidip, "seçim ertelensin" çalışması yaparken, Cem Uzan özel uçakla seçmene gidiyor... 1950'lerin Fransa'sında, Poujade adlı bir kişi, "Vergileri kaldıracağım" diyerek, 100'ü aşkın milletvekili çıkarmıştı... Şimdiki Le Pen de, bu Poujade'in ögrencisiydi... Yani, "olmaz olmaz" deyin!..." (Yeni Şafak, 15 Eylül 2002).

Hasan Cemal'in (Milliyet, 16 Ekim 2002), "Bu seçimlerde ilk kez oy kullanacak yeni seçmenlerin yüzde 20-22 'sinin GP'yi, yüzde 30-35' 'inin AKP'yi tercih etmesi bekleniyor. GP'nin kendi oy ortalamasi göz önünde tutulduğunda bu cran çok yüksek... Özellikle büyük kentlerin yoksul, işsiz ve eğitimsiz gençleri arasında büyük ölçüde tercih edilen parti, Uzan'in GP'si... Buna karşılık kirsal bölgelerin yoksul, eğitimsiz gençleri daha çok AKP'yi tercih ediyor" şeklindeki ifadesinin yer aldığı köşe yazısı, popülizmin ve GP'nin yükselişini ifade ederken; seçmenin, iki seçim arası dönemde sürecin etkisiyle kritik yeniden saflaşmasının da bir ifadesidir.

14 Ağustos 2001 tarihinde Ak Parti’nin kurulmasının ardından halka seslenen Recep Tayyip Erdoğan, “Bugünden sonra artık Türkiye'de hiçbir şey eskisi gibi olmayacak. Biz buna inanıyoruz, bundan sonra da bize güvenin diyoruz " söylemiyle erken seçim çağrısı yapmıştır (Hürriyet 14 Ağustos 2001). Ak Parti'nin 2002 seçim sloganı bu söylemler ile paralel yönde, "Her şey Türkiye için", "Yasaksız Türkiye", "Yoksulluk ve yolsuzlukla mücadele" ve "AB'ye tam üyelik" şeklindedir (CNN Türk 10 Temmuz 2014). Dönemin seçim kılavuzu incelendiğinde partinin kullandığı materyallerinin hedef kitleye göre düzenlediği ve tıpkı GP gibi teknolojinin bütün imkânlarından yararlandığı anlaşılmaktadır (Ak Parti Medya ve Tanıtım Başkanlığı, 2002, s. 4-5). Erdoğan'ın "hiçbir şey eskisi gibi olmayacak" söylemi, mevcut koalisyon hükümetine bir eleştiri iken; bu söylemin halk nezdinde bir umut ve beklenti yarattı̆̆1 söylenebilir. Öte yandan bir önceki başlıkta belirtildiği üzere, oy katılımının bir önceki seçimlere göre gerilemesi (\%87.1'den \%79.1'e) halk üzerinde geçici olmayan siyasi, ekonomik ve toplumsal bir rahatsızlığın sonucudur. Dolayısıyla seçmen davranışı bu koşullardan etkilenerek oya katılmada bir düşüş yaratmış ancak iktidardaki koalisyon hükümeti azınlığa düşmüştür. Böylece DSPMHP-ANAP partilerinin oyları düşmüş ve Ak Parti tek başına hükümeti kuracak yeterli oyu almıştır. Kasım 2002 seçimleri bu anlamda kritik bir seçimdir. Ak Parti'nin iktidara gelmesinin yanında seçimlerde GP'nin de oylarını artırması, seçmenin kritik yeniden saflaşmasının bir ifadesidir.

Çaha'nın yaptığı değerlendirmeye göre Ak Parti’nin iktidara gelişi, "1lımlı modernleşme" paradigmasının bir devamıdır. Adem-i merkeziyetçi bir siyasal yapı, temel hak ve hürriyetler, siyasal özgürlükler, serbest piyasa ekonomisi ve özelleştirmeler gibi değerler modern değerler kapsamında iken; yerel değerlerin üst çatısı olarak da İslam esas alınmıştır (2008, s. 228). Bu çerçevede Çarkoğlu ve Binnaz'ın yaptığı çalışmaya tekrar değinecek olursak, Ak Parti iktidarına yönelik yaptıkları değerlendirmeye göre, DSP-MHP-ANAP koalisyon hükümetiyle karşılaştırıldığında yüksek bir değişim sürecinin olduğu anlaşılmaktadır. Dahası değişimi olumlu görenler -muhafazakâr, kendini dindar ve İslamcı kesime yakın gören, görece düşük sosyo-ekonomik statüde, kırsal kesimden seçmenler- olumsuz görenlerden daha fazladır ${ }^{8}$ (Çarkoğlu ve Toprak, 2006, s. 31). 2002 seçimlerinde İslam'ın esas almasının

8 Laçiner (2002), “AKP, rakibi diğer büyük(çe) partiler gibi yürürlükteki iktisat politikalarını ana hatları ile sürdüreceğini yine onlar gibi AB'ye katılmayı hedeflediğini söylüyor ve sadece “tek başına, iş başına” geçerek dürüst, işbilir, çalışkan bir yönetim vaadediyordu. Bu fikir ve görüşleriyle ötekilerden hiç de farklı değillerdi, şahsi sicilleri 
yanı sıra merkez sağ partilerin (DYP, ANAP) \%10'luk barajı geçememesi, Türk siyasetinde büyük bir değişim olduğunun ifadesidir (Coşar ve Özman, 2004, s. 57). Ak Parti’nin 2002 seçim bildirgesi analiz edildiğinde, söz konusu paradigmanın içeriği ve değişim sürecine yol açan kritik yeniden saflaşmanın sebepleri anlaşılabilir,

\begin{abstract}
"Partimiz, ülkemizin genç ve dinamik nüfusu, eşsiz coğrafi konumu, zengin doğal kaynaklart ve engin kültür birikimi ile yeni dünyanın etkin bir üyesi olma potansiyeline sahip olduğunu düşünmekte ve bütün bu olup bitenleri hak etmediğine inanmaktadır. Krizin sorumlusu halkımız değildir. Krizin sorumlusu ülkeyi yönetenlerdir. Milletimizin bu kötü gidişe dur demesi için 3 Kasım seçimi önemli bir firsattır. Kronik hale gelen yüksek işsizlik ve enflasyonu, sürekli artan iç ve dış borçları, ekonomideki istikrarsızlık ve tehlikeli daralmayl, yüksek faiz oranlarını, tasarrufları kamu açıklarının finansmanına yönlendiren borç yönetimi anlayışını aşarak ülkeyi düze çıkaracak bir siyasi iradeye ihtiyaç vardır" (Ak Parti Seçim Bildirgesi, 2002).
\end{abstract}

Kriz, dış borç, istikrarsızlık, faiz oranları gibi konularda önceki hükümeti her firsatta eleştiren Ak Parti, aynı zamanda yeni dünyaya eklemlenme, umut ve güven dolu bir gelecek vaadiyle genç ve dinamik nüfusa seslenmiştir. Bu noktada Çaha, Ak Parti'nin iktidara gelişinin arkasında yatan faktörlerin ekonomik kalkınmayı sağlama, yolsuzlukla mücadele ve temel hak ve hürriyetler konusunda genişleme sağlaması yönündeki toplumsal beklentilerin olduğunu ifade etmektedir. Çünkü önceki yönetimde İslamc1-Muhafazakar çevrenin dışlanması, deprem felaketinin toplumda travma yaratması ve ekonomiye olumsuz yönde etkisi, 1998-2001 ekonomik krizleri, yolsuzluklar toplum nezdinde rahatsızlıklara yol açmıştı (2008, s. 236-237). Özellikle toplumsal alanda yaşanan ekonomik zorluklar, seçim süreci içerisinde Ak Parti'nin temel söylemlerinin de merkezinde olmuştur. Daha önce çalışmada da değinildiği gibi Ak Parti'nin iktidara gelmesinde etkili olan bu faktörde, kamuoyunun önceki yönetimlere duymuş olduğu öfke ve güvensizlik etkili olmuştur. Çünkü kamuoyu mikro ekonomik bağlamda devletlerin çıkarlarının ve eylemlerinin çokta dışsal olmayan yapılar tarafından oluşturulduğunu düşünmektedirler (Wendt, 1995, s. 72-73). Bu nedenle kritik seçim teorisi baz alındığında kamuoyu mevcut sorunları koalisyonlar ile ilintili kabul ederek, istikrar bağlamında tek bir hükümetin yönetimini rasyonel bir tercih olarak görüldüğü söylenebilir. Seçmenler devlet aygitlarının güçlendirilmesi, yoksulluk ile mücadele, kendini fakirlik sınırından kurtaracak, çocuğunun geleceğini garanti altına almasını sağlayacak, ülkenin önünü açacak yeni enerjilere ihtiyaç duyduğunu söyleyerek yeni partilere oy vermekten kaçınmamıştır (Gürel, 2007, s. 137). Bu durum daha önce değinildiği gibi seçimlerde GP, Ak Parti gibi yeni partilerin başarı elde etmesi ile sonuçlanmıştır. Nitekim Ak Parti'nin 2002 Yolunda Ak Parti Seçim Beyannamelerinin içeriğine bakıldığında devletin değişen rolü, özelleştirmeler, demokrasi, temel hak ve özgürlükler, işsizlik, yolsuzlukla mücadele, AB ilişkiler, dış borç, nitelikli eğitim, nitelikli sağlık hizmeti, hukuk, adalet gibi birçok konu ve soruna yer verdiği görülmektedir (Ak Parti Tanıtım ve Medya Başkanlığı, 2015).

Öte yandan Wendt'in işaret ettiği ulusal çıkarlar, özerklik, ekonomik refah, kolektif özsaygı, fiziki beka ihtiyaçlarının bir önceki hükümet tarafından karşılanmamasının 2002 genel seçimlerinde önemli rol oynadığı görülmektedir. Nitekim fiziki beka bağlamında "Komşularla Sıfır Sorun Politikası" Ortadoğu'daki aktörlerle yakın ilişkiler gündeme alınmıştır (Sınır, 2019, s. 25). Kolektif öz saygı bağlamında merkez ve düzen kurucu ülke kavramı, proaktif ve uzlaştırıcı diplomasi, insani diplomasi söylemlerinin ön plana çıktığı görülmektedir (Akıllı, 2016, s. 108-129). Özerklik ve ekonomik refah bağlamında ise sosyal devlet kavramı, işsizliğin ve yoksulluğun azaltılması, kalkınma ve adalet söylemi dikkat çekmektedir. Böylelikle kimlik faktörü de dahil olmak üzere bu söylemler Ak Parti’nin seçmene seslenişinde önemli bir rol oynamıştır. Seçmenin oy verme davranışlarını da etkileyen bu gelişmeler çalışmada da belirtildiği gibi kritik seçim ve kritik yeniden saflaşma teorisi çerçevesinde değerlendirildiğinde Ak Parti'ye yönelimi artırmıştır. Nitekim daha önce ANAP'a oy veren bir seçmen, sonraki seçimlerde kemikleşmiş partilerin özellikle DYP, ANAP, MHP, DSP'de yeniliğe, yeni liderlere

ile onlardan daha inandırıcı bir kadro olmalarıydı onları ‘yükselten'...” şeklinde bir değerlendirme yapmıştır.

IBAD Sosyal Bilimler Dergisi / IBAD Journal of Social Sciences, (Özel Sayı/Special Issue), 2020 
ihtiyacı olduğunu varsayarak CHP, GP veya Ak Parti’ye oy vermede bir sakınca görmemiştir (Gürel, 2007, s. 137).

\section{SONUÇ}

Demokratik toplumlarda seçimlerin işlevleri, halkın yönetime katılımının sağlanması ve hükümetin oluşması sonucuna ulaşılmasıdır. Seçimler aracılığıyla seçmenler, iktidarı elinde bulunduranlardan hesap sorabilir, iktidarın tasarruflarını kabul edebilir veya bir sonraki seçimlerde oy verdiği partiyi değiştirme kararı alabilir. Bu nedenle seçimler salt bir seçme eylemi değil, bir sürecin de parçasını oluşturmaktadır. Böylelikle seçim yoluyla siyasi katılımın sağlanmasında süreç içerisinde çeşitli faktörler etkili olabilmektedir. Zira siyasi, sosyo-ekonomik, psikolojik, kültürel ve hatta çevresel faktörler seçmenin oy verme davranışı üzerinde belirleyicidir. Oy verme davranışı ile ilişkili sosyolojik, psikolojik, rasyonel veya stratejik gibi çeşitli varsayımlar mevcuttur. Bu varsayımlar, seçmen davranışının karmaşık ve çok boyutlu olduğunun bir ifadesidir.

Türkiye'de 1999-2002 yılları arasında gelişen iç ve dış dinamikler, seçmenin oy verme davranışı üzerinde etkili olmuştur. Bu etmenler sonucunda seçmenler, 3 Kasım 2002 seçimlerinde yeni bir partiye oy vermeyi denemiştir ve seçim sonuçları sürpriz olarak karşılanmıştır. Nitekim henüz seçimlerden çok kısa bir süre önce örgütlenen liberal-popülist bir parti olan GP yükselişe geçerken; kökeni Milli Görüş’e dayanmakla birlikte liberal-muhafazakâr bir parti olan Ak Parti, tek başına hükümeti kurabilecek oyların çoğunluğunu almıştır. Bu partilerin seçim bildirgeleri, liderlerin miting konuşmaları ve elbette ki seçim sonuçları seçmenin kritik yeniden saflaşmasının ifadesidir ve kritik seçim teorisi ile örtüşmektedir.

Bu bağlamda, 1999-2002 yılları arasındaki süreçte yaşanan toplumsal, siyasal, ekonomik ve psikolojik olumsuz sürece dair iç ve dış dinamikler, seçmenlerin oy verme davranışı üzerinde etkili olmuştur denilebilir. 28 Şubat süreci sonrası yaşananlar, depremin getirdiği yıkım, ekonomik kriz, işsizlik, yoksulluk, yolsuzluk ve terör faaliyetlerinin etkileri seçim sonuçları üzerinde etkili olmuştur. Diğer yandan partilerin yürüttükleri seçim çalışmaları, kullandıkları söylemler ve verdikleri vaatler halk nezdinde olumlu karşılanmıştır. Zira GP'nin retoriği halk üzerinde etkili olurken; seçim çalışmalarında kullandığı yöntemler halkın desteğini almakta başarı sağlamıştır. Ancak GP oylarını artırarak yükselişe geçmiş olsa bile hükümeti kuracak yeterli oy sayısına ulaşamamıştır. Ak Parti ise seçim çalışmalarında halka seslenirken; yoksulluk ve yolsuzlukla mücadeleyi hedeflediğini seçim bildirgesinde ve söylemlerinde sıklıkla dile getirmiştir. Öte yandan siyasal yapı, serbest piyasa ve siyasi özgürlükler modern değerler olarak benimsenirken; İslam kapsayıcı bir üst çatı belirlenmiştir. Bu durum bir önceki hükümet ile karşılaştırıldığında bir değişimi ifade etmektedir. Böylelikle Ak Parti muhafazakâr, dindar, İslamcı ve düşük sosyo-ekonomik seçmenin oylarını almayı başarmıştır. Fiziki beka, müşterek öz saygı, ekonomik refah, özerklik bakımından toplumsal açıdan önceki hükümetlere olan güvensizlik, seçmenin kritik yeniden saflaşması minvalinde tercihlerini yeni partilerden yana kullanmaları ile sonuçlanmıştır. Zira bunun bir yansıması olarak daha önce hükümet ortağı olan birçok parti seçim barajını geçememiş ve seçimlerde başarısız olmuşlardır.

$\mathrm{Bu}$ çerçevede iktidarın değişmediği seçimlerden farklı olarak kritik seçimlerde, seçmen tabanında radikal oy kaymaları meydana gelir ve iktidardaki parti uzun soluklu olacak biçimde el değiştirir. 2002 genel seçimlerinde seçmenlerin \%54'ü başka bir partiyi denemişlerdir. Ancak Tosun, Ak Parti ve GP'nin sisteme yeni katılan partiler olarak yükselişleri nedeniyle 2002 genel seçimlerini kritik seçim olarak değerlendiremeyeceğimizi ifade etmiştir. Nitekim seçmenlerin bu yeni partiler etrafında saflaşmasının uzun sürüp sürmeyeceğini çözümlemek, 2003 yılı için erken bir tahmin olarak görülmüştür (Tosun, 2003, s. 365-367). 2002 genel seçimlerinin ardından GP'nin oyları düşüşe geçmiş olsa da günümüze kadar yapılan genel seçimlerde Ak Parti tek başına iktidarda kalabilmiştir. Böylelikle seçimleri kritik yeniden saflaşma ve kritik seçim teorisi minvalinde değerlendirebilmek için, seçim sonucunda iktidara gelen partinin uzun soluklu olması gerekmektedir. Bir sonraki genel seçimlerde (2023 yılında yapılması beklenen) seçmen tabanında ani ve beklenmedik oy kaymalarının yaşanması veyahut yaşanmaması, seçim tipinin niteliğini belirleyecektir. 


\title{
Bilgilendirme / Acknowledgement:
}

\author{
Yazarlar aşağıdaki bilgillendirmeleri yapmaktadırlar: \\ 1- Araştırmacıların katkı oranı eşittir. \\ 2- Makalenin yazarları arasında çıkar çatışması bulunmamaktadır. \\ 3- Makalemizde etik kurulu izni ve/veya yasal/özel izin alınmasını gerektiren bir durum yoktur. \\ 4- Bu makalede araştırma ve yayın etiğine uyulmuştur.
}

\section{KAYNAKÇA}

Abadan, N. (1965). Ankara şehir nüfusunun siyasi eğilimlerinden bazı örnekler. Ankara Üniversitesi Siyasal Bilgiler Fakültesi Dergisi, 26(1), 496-517.

Abadan, N. ve Yücekök, A. N. (1966). 1961-1965 seçimlerinde büyük şehirlerde gelir durumuna göre oy verme davranışları. Ankara Üniversitesi Siyasal Bilgiler Fakültesi Dergisi, 21(4), 102118.

Akıllı, E. (2016). Türkiye'de devlet kimliği ve dış politika. Ankara: Nobel Akademik Yayıncılık.

Akkılıç, M.E., M.O. İlban ve Özbek, V. Siyasi partilerin uyguladığı pazarlama anlayışının ve hedef pazar stratejisinin seçim başarısı üzerine etkisi. Balıkesir Üniversitesi Sosyal Bilimler $\begin{array}{lllll}\text { Enstitüsü } & \text { Dergisi. } & 21 & \text { Haziran } & 2020 \\ \end{array}$ http://sbe.balikesir.edu.tr/dergi/edergi/c14s26/makale/215-240.pdf adresinden erişildi.

Ak Parti Medya ve Tanıtım Başkanlığı (2002, 3 Kasım). Teşkilatlar ve milletvekili adayları için seçim kılavuzu. 27 Haziran 2020 tarihinde http://www.akparti.org.tr/media/272301/2002-secimkilavuzu.pdf adresinden erişildi.

Ak Parti Seçim Bildirgesi (2002). 31 Ağustos 2019 tarihinde https://kurzman.unc.edu/files/2011/06/AKP_2002.pdf adresinden erişildi.

Ak Parti Tanıtım ve Medya Başkanlığ (2015). 2002 yolunda Ak Parti seçim beyannameleri. 24 Haziran 2020 tarihinde https://www.akpartibingol.org.tr/media/318780/3-kasim-2002-genelsecimleri-secim-beyannamesi-sayfalar.pdf adresinden erişildi.

Aktürk, İ. ve Albeni, M. (2002). Doğal afetlerin ekonomik performans üzerine etkisi: 1999 y1lında Türkiye'de meydana gelen depremler ve etkileri. Süleyman Demirel Üniversitesi İktisadi ve İdari Bilimler Fakültesi Dergisi, 7(1), 1-18.

Atlığlu, Y. (2009). Suriye dış politikasında güç ve güvenlik ilişkisi. Bilge Strateji, 1(1), 71-87.

Aydoğan Ünal, B. (2016). Oy verme davranışı modelleri. OÜSOBİAD, 95-119.

Barlas, M. (2002, 15 Eylül). Ya Cem Uzan'nın “Genç Partisi” iktidar olursa. Yeni Şafak. 24 Haziran 2020 tarihinde https://www.yenisafak.com/arsiv/2002/eylul/15/mbarlas.html adresinden erişildi.

Bora, T. (2002). 2002 Seçimi ve siyasî güzergâh problemleri. Birikim, 163-164. 4 Kasım 2020 tarihinde https://birikimdergisi.com/dergiler/birikim/1/sayi-163-164-kasim-aralik2002/2352/2002-secimi-ve-siyasi-guzergah-problemleri/2554 adresinden erişildi.

Boratav, K. (2011). Türkiye iktisat tarihi: 1908-2009. Ankara: İmge Kitabevi Yayınları.

Cemal, H. (2002, 16 Ekim). 'Damardan Popülizm' ya da GP’nin Yükselişi!. Milliyet. 21 Haziran 2020 tarihinde https://www.milliyet.com.tr/yazarlar/hasan-cemal/damardan-populizm-ya-da-gpnin-yukselisi-5201013 adresinden erişildi. 
CNN Türk. (2014, 10 Temmuz). Unutulmaz seçim sloganları. 27 Haziran 2020 tarihinde https://www.cnnturk.com/fotogaleri/guncel/unutulmaz-secim-sloganlari?page=1 erişildi.

adresinden

CNN Türk. (2014, 17 Aralık). En Unutulmaz seçim vaatleri. 20 Haziran 2020 tarihinde https://www.cnnturk.com/fotogaleri/yasam/diger/en-unutulmaz-secim-vaatleri adresinden erişildi.

Coşar, S. ve Özman, A. (2004). Centre-right politics in Turkey after the November 2002 general election: neo-liberalism with a Muslim face. Contemporary Politics, 10(1), 57-74.

Çaha, Ö. (2008). Türkiye'de seçmen davranışı ve siyasi partiler. Ankara: Orion Kitabevi.

Çarkoğlu, A. ve Toprak, B. (2006). Değişen Türkiye'de din, toplum ve siyaset. TESEV: Türkiye Ekonomik ve Sosyal Etüdler Vakfı Demokratikleşme Programı.

Çayhan, E. (2002). Avrupa güvenlik ve savunma politikası ve Türkiye. Akdeniz Üniversitesi İktisadi ve İdari Bilimler Fakültesi Dergisi, 2(3), 53-54.

Çelik, F. (2017). 28 Şubat döneminde (1991-2002) Türkiye'de siyaset: Ak Parti dönemine kadar. Osmanlı'dan Günümüze Türkiye'nin Siyasal Hayatı. Ankara: Savaş Yayınevi.

Darmofal, D. ve Nardulli, P. F. (2010). The dynamics of critical realignments: an analysis across time and space. Political Behavior, 32(2), 255-283.

Derman, J. (2012). Max Weber in politics and social thought: from charisma to canonization. England: Cambridge University Press.

Dikici Bilgin, H. (2016). Seçimler ve seçim sistemleri. (Ed. Sayarı, Sabri ve Dikici Bilgin, Hasret) Karşılaş̧tırmal siyaset: temel konular ve yaklaşımlar içinde. İstanbul: İstanbul Bilgi Üniversitesi Yayınları.

Erdağ, R. (2013). Ali Balcı, Türkiye dış politikası: İlkeler, aktörler, uygulamalar. Uluslararası İlişkiler Dergisi, 10(40), 172-178.

Esmer, Y. (2002). At the ballot box: determinants of voting behavior. (Ed. Sabri Sayar1 ve Y1lmaz Esmer). Politics, parties and elections in Turkey içinde. Boulder London: Lynne Rienner Publishers.

Evans, G. ve Norris, P. (2016). A critical election? Understanding the 1997 British election in longterm perspective. 17 Nisan 2020 tarihinde file:///C:/Users/Lenovo/Downloads/A_CRITICAL_ELECTION_UNDERSTANDING_THE_ 1997_BRITISH.pdf adresinden erişildi.

Fırat, E. (2009). Türkiye'de 1980 sonrası yaşanan üç büyük kriz ve sonuçlarının ekonomi-politiği. Sosyal Ekonomik Araştırmalar Dergisi, 9(17), 501-524.

Gürel, T. (2007). Türk siyasi tarihinde "Muhafazakârllk" kimliği ve AKP örneği incelemesi. Yayınlanmamıs doktora tezi, Marmara Üniversitesi, İstanbul.

Gökçe, O., Akgün, B. ve Karaçor, S. (2002). 3 Kasım seçimlerinin anatomisi: Türk siyasetinde süreklilik ve değişim. SÜ İ̈BF Sosyal ve Ekonomik Araştırmalar Dergisi, 2(4), 1-44.

Hazama, Y. (2006). Retrospective voting in Turkey: Macro and micro perspectives. Institute of Developing Economies, 46, 1-18.

Hürriyet. (2001, 14 Ağustos). Erdoğan: Hiçbir Şey eskisi gibi olmayacak. 21 Haziran 2020 tarihinde http://www.hurriyet.com.tr/gundem/erdogan-hic-bir-sey-eskisi-gibi-olmayacak-10050 adresinden erişildi.

İpekşen, S. S. ve Duman, D. (2015, 26 Mayıs). 2002: Ezber Bozan Seçim. Bianet. 3 Kasım 2020 tarihinde https://bianet.org/bianet/bianet/164720-2002-ezber-bozan-secim adresinden erişildi. 
Jr., V. O. Key (1959). Secular realignment and the party system. The Journal of Politics 21 (2). 198210. 19 Haziran 2020 tarihinde https://doi.org/10.2307/2127162 adresinden erişildi.

Jr., V. O. Key (2014). A theory of critical elections. The Journal of Politics 17(1), 3-18.

Kapani, M. (2012). Politika bilimine giriş. Ankara: Bilgi Yayınevi.

Kavak, E. D. (2017). Türkiye'de seçim kampanyalarının Amerikanvarileşmesi: Adalet ve Kalkınma Partisi ve karizmatik lider imgesinin medyada inşası. Yayınlanmamış yüksek lisans tezi, Hacettepe Üniversitesi, Ankara.

Keskin, H., Kiriş, H. M., ve Şentürk, C. (2006). 2001 krizinin ekonomik ve siyasi yönleri üzerine bir değerlendirme çabası. Süleyman Demirel Üniversitesi Sosyal Bilimler Enstitüsü Dergisi, (4), 46-73.

Laçiner, Ö. (2002). DP, ANAP ve sonunda AKP. Birikim. 4 Kasım 2020 tarihinde https://birikimdergisi.com/dergiler/birikim/1/sayi-163-164-kasim-aralik-2002/2352/dp-anapve-sonunda-akp/2552 adresinden erişildi.

Macovei, M. (2009). Growth and economic crises in Turkey: leaving behind a turbulent past?. Directorate General Economic and Financial Affairs (DG ECFIN), 386. European Commission.

Newton, K. ve van Deth, J. W. (2014). Karşılaştırmalı siyasetin temelleri. (Çev. Esin Saraçoğlu). Ankara: Phoenix Yayınevi.

Nuhrat, C. (1971). Türkiye köylerinde olağandışı oy verme. Anakara Üniversitesi SBF Dergisi, 26(1), 219-244.

Özbudun, E. (2016). Türkiye'de parti ve seçim sistemi. İstanbul: İstanbul Bilgi Üniversitesi Yayınları.

Özbudun, E. ve Tachau, F. (1975). Social change and electoral behavior in Turkey: toward a critical realignment. Int. J. Middle East Stud., 6, 460-480.

Robert, P. ve Papp, Z. (2012). Critical elections? Party identification and party preference at the 2010 Hungarian general elections. Mtatkpti. MTA TK Politikatudomany Intezet. The 2012 Elections, Oxford: Public Opinion and Parties (EPOP) Conference, 7th to 9th September Panel: Eastern and Central Europe. 1-24.

Sayın, Y. (2016). Türkiye'nin Avrupa Birliği'ne katılım müzakereleri ve müzakere fasılları. Selçuk Üniversitesi Sosyal Bilimler Meslek Yüksekokulu Dergisi, 19(2), 41-62.

Sınır, G. (2019). Türkiye'nin kimlik değiş̧imi bağlamında Türkiye-Suriye ilişkileri (1990-2010). Namık Kemal Üniversitesi Sosyal Bilimler Meslek Yüksek Okulu Dergisi, 1(1), 19-27.

Sisk, T. D. (2017). Elections, electoral systems and party systems. Stockholm: International Institute for Democracy and Electoral Assistance.

Şahin, M. (2014). Türkiye'nin Ortadoğu politikası: süreklilik ve değişim. (Ed. İdris Demir). Türkiye'nin dış politikası yeni eğilimleri, yeni yönelimleri, yeni yaklaşımları içinde. Bursa: Dora Yayınları.

Taner-Özkeçeci, B. (2012). Koalisyon hükümetleri ve Türk dış politikasının oluşturulması. (Ed. Ertan Efegil ve Rıdvan Kalaycı). 271-287. Dış politika teorileri bağlamında Türk dı̧̧ politikasının analizi içinde. Ankara: Nobel Yayınları.

Tosun, T. (2003). Siyasette yeniden mevzilenmeler: Liberal sosyal sentez, muhafazakâr demokrat sentez ekseninde 3 Kasım 2002 seçimleri. İstanbul: Büke Kitapları.

Türk, H. B. (2007). Genç Parti'yi anlamak: parti, lider ve kitle üzerine bir çalışma. Yayınlanmamış doktora tezi, Ankara Üniversitesi, Ankara. 
Türk Mühendis ve Mimar Odaları Birliği (TMMOB) (2001). Güçlü ekonomiye geçiş programı üzerine değerlendirmeler. Bă̆ımsız Sosyal Bilimciler-Ikktisat Grubu. 29 Haziran 2020 tarihinde https://www.tmmob.org.tr/sites/default/files/f96613235062963_ek.pdf adresinden erişildi.

Türkiye İstatistik Kurumu (TÜİK) (2012). Milletvekili genel seçimi il ve ilçe sonuçlart, general election of representatives province and district results 2011, 2007, 2002, 1999, 1995, 1991. Ankara.

Türkiye'nin Güçlü Ekonomiye Geçiş Programı. (2001). 27 Haziran 2020 tarihinde https://www.tcmb.gov.tr/wps/wcm/connect/26640b7b-9641-4c35-99eccd10a9d4e51b/program.pdf?MOD=AJPERES\&CACHEID=ROOTWORKSPACE-26640b7b9641-4c35-99ec-cd10a9d4e51b-m3fB7oF adresinden erişildi. 1-30.

von Mettenheim, K. (2009). The theory of critical elections and realignment: an alternative paradigm for understanding party change in Brazil. 1-36.

Wendt, A. (1995). Constructing international politics. International Security, 20(1), 71-81.

Wendt, A. (1992). Anarchy is what states make of it: the social construction of power politics. International Organization, 46(2), 391-425.

Wendt, A. (2016). Uluslararası siyasetin sosyal teorisi. (çev. Helin S. Ertem Vd.). İstanbul: Küre Yayınları.

Yalnız, M. (2004). Siyasal reklam-Genç Parti'nin 3 Kasım 2002 seçim kampanyası. Yayınlanmamış yüksek lisans tezi, Marmara Üniversitesi, İstanbul.

Yeşiltaş, M. ve Pınar, B. vd. (2015). Türkiye dünyanın neresinde? Hayali coğrafyalar, çarpışan anlatılar. İstanbul: Koç Üniversitesi Yayınları.

Yıldırım, D. (2010). 2001 krizi sonrasında bir hegemonya projesi olarak AKP'nin doğuşu. Yayınlanmamış doktora tezi, Ankara Üniversitesi, Ankara.

Yüce, Y. (2012). Türkiye'de siyasi partilerin dış politika programları (1983-2007). Yayınlanmamış yüksek lisans tezi, Adnan Menderes Üniversitesi, Aydın. 